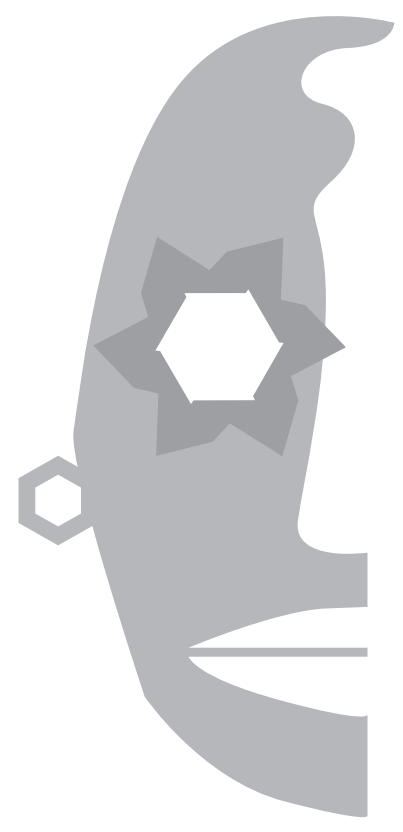

\title{
La sed
}

Axel Tassara (1963) es un autor costarricense, con más de 30 años de carrera literaria combinada con la publicidad y la gestión cultural. Publicó en 1982 el poemario Clima de Geranios mediante una edición propia, y posteriormente el escritor fue galardonado en dos ocasiones con el Premio UNA Palabra. La primera vez, en el año 2004 en la rama de poesía, por su libro Las Legiones de Octubre, concebido en San Rafael de Alajuela y publicado en 2005 por la Editorial de la Universidad Nacional (EUNA), el cual se inspira en la lluvia como su tema principal.

Recibe el mencionado premio por segunda vez en 2017, en la categoría de cuento, por su obra El Jardín de las Mareas, escrito en Palmares y cuya publicación por la EUNA está prevista en 2018. La fluidez del agua, en su ir y venir por los mundos que le habitan al autor, parece que continúa siendo un leitmotiv del resto de su obra, aún la inédita, como se refleja con humor en este cuento breve que la Revista Ístmica reproduce en esta edición, bajo el influjo de los aguaceros tropicales que circundan el istmo. 


\section{La sed}

Le despertó la lluvia que, furiosa, aporreaba el balcón y los ventanales. Le parecía escucharla reventarse contra la calle, 14 pisos más abajo. Apenas podía mover los párpados. Abrir los ojos sería difícil aquella mañana. Aún rugía en su cabeza todo el jolgorio de la noche anterior: los distintos cocteles, las drogas, el mal sexo, los muchos cigarrillos fumados sin misericordia. Afuera la tormenta golpeaba con más fuerza, era como si toda el agua, de todos siglos, se estuviera ensañando contra la ciudad, tratando de lavarle las faltas y los pecados. De repente tuvo ganas de orinar, de beberse de golpe un litro de agua.

Se incorporó despacio, los ojos aun cerrados, el traqueteo de la lluvia retumbando en los oídos. Los párpados ascendieron lentamente. El cuarto estaba en penumbras. Miró el reloj (once menos cuarto), apenas había dormido tres horas. Ponerse de pie fue todo un ejercicio de voluntad y coraje. Caminar el trecho entre la cama y el baño le pareció una gesta titánica. Era como si todos los dolores, de todos los siglos, se hubieran acomodado esa mañana de invierno en su escuálido cuerpo.

Le costó orinar, así era desde hacía unos meses, unos amigos decían que era la vejiga, otros que la próstata. Se miró en el espejo, la imagen al otro lado no decía nada, no era necesario. Se inclinó sobre el lavabo, quería tomar largos segundos de agua. Abrió la llave. Nada. Ni una gota salió del tubo, tan solo un ahogado sonido, como sería de ahogado el último gemido de un náufrago. Fue a la cocina. Lo mismo sucedió allí. ¿Había pagado la factura? Sí, se la descontaban de la tarjeta de débito. ¿Qué pasaría? De repente lo recordó, lo había leído en una noticia del diario: Este sábado no habrá servicio de agua potable, Acueductos suspendía temporalmente el servicio de ocho a cuatro; algo de un arreglo en el tubo madre. También recordó la circular que había repartido el de mantenimiento, indicando que aprovecharían ese día para solucionar un desperfecto en la bomba. Lo había olvidado y no tenía agua almacenada. Buscó en la refrigeradora y luego en la despensa, lo único liquido era media botella de sirope, una botella de vinagre y un fondo de vodka. Se sintió mal, la náusea provocada por la resaca y la sed complicaba las cosas. Sentía la garganta y la lengua rígida, como si fueran de cartón o yeso. La escasa saliva maltrataba igual que un cactus. No conocía a los vecinos, absurdo sería pedirles de su agua; tampoco tenía deseos de bajar al supermercado. Fue cuando pensó, "daría lo que fuera, en este momento, por un puto trago de agua". 
El aguacero arreciaba. Era irónico, tanta agua cayendo y él muriendo por un trago. Tomó un vaso limpio de la cocina y caminó hacia el balcón. Corrió la puerta. Un viento frío y húmedo inundó la estancia. Dio un paso hacia afuera, el voladizo era amplio, tendría que estirar mucho el brazo para alcanzar a llenar su vaso con agua de lluvia. Grandes gotas le golpeaban el rostro, capturaba con su boca cuantas podía. Se estiro más, el vaso no se llenaba, así que sacó medio cuerpo de la baranda, abajo la ciudad lucía anegada; pequeñas figuras se desplazaban por el Paseo Colón en busca de refugio. Estaba empapado. Se estiró cuanto pudo, ya el vaso llevaba lleno poco menos de un cuarto. "Un poco más, más, tan solo un poco más". Levantó una pierna y la colocó sobre la baranda. Ahora su cuerpo se mecía en precario equilibrio. No le importó el vacío, la tormenta, el viento; San José que ahora desaparecía bajo un jergón de niebla. Nada, no le importó nada, tan solo quería un largo sorbo de agua.

Los vecinos, que poco le veían, aún se preguntan, varios meses después, qué motivos habría tenido aquel exitoso ejecutivo para saltar de su balcón, aquella lluviosa mañana de octubre. 